\title{
Evolution and natural selection: learning by playing and reflecting
}

\author{
David Herrero ${ }^{1 *}$, Héctor del Castillo², Natalia Monjelat ${ }^{3}$, Ana Belén García-Varela ${ }^{4}$, \\ Mirian Checa ${ }^{5}$, Patricia Gómez ${ }^{6}$ \\ 'Department of Educational Sciences, University of Alcalá, Spain \{david.herrero@uah.es\} \\ 2Department of Educational Sciences, University of Alcalá, Spain \{hector.delcastillo@uah.es\} \\ ${ }^{3}$ Department of Educational Sciences, University of Alcalá, Spain \{natalia.monjelat@uah.es\} \\ ${ }^{4}$ Department of Educational Sciences, University of Alcalá, Spain \{abelen.garcia@uah.es\} \\ ${ }^{5}$ Department of Educational Sciences, University of Alcalá, Spain \{m.checa@uah.es\} \\ ${ }^{6}$ Department of Educational Sciences, University of Alcalá, Spain \{patricia.gomezh@edu.uah.es\} \\ Received on 2 September 2013; revised on 5 September 2013; accepted on 30 September 2013; published on 15 January 2014
}

DOI: 10.7821/naer.3.1.26-33

\begin{abstract}
Scientific literacy is more than the simple reproduction of traditional school science knowledge and requires a set of skills, among them identifying scientific issues, explaining phenomena scientifically and using scientific evidence. Several studies have indicated that playing computer games in the classroom can support the development of students' conceptual understanding about scientific phenomena and theories.

Our paper presents a research study where the role of the video game Spore as a learning tool was analysed in a Biology class. An ethnographical perspective served as the framework for the organization and development of a workshop comprised of five sessions with $224^{\text {th }}$ grade students, and their Biology teacher. The results show that this video game could become an interesting learning tool to improve students' understanding of evolution and natural selection. The students could combine their previous knowledge with the academic knowledge obtained though the simulation presented by the video game.

To sum up, an attempt has been made to give some empirical guidance about effective approaches to the utilisation of games in classrooms, additionally paying attention to a number of concerns related to the effectiveness of video games as learning tools.
\end{abstract}

KEYWORDS: COMPUTER GAMES, SCIENCE EDUCATION, ETHNOGRAPHY, SECONDARY EDUCATION, LEARNING STRATEGIES

\section{INTRODUCTION}

When it was too early to consider the educational potential of video games, there were already concerns over how to present information to students in schools. Dewey (1910) believed that science should be presented as something more than a collection of isolated facts so that it could promote and develop scientific

\footnotetext{
*To whom correspondence should be addressed:

Departamento de Ciencias de la Educación

Universidad de Alcalá

C/ San Cirilo, s/n. 28801

Alcalá de Henares, Madrid

Spain
}

attitudes as well as interest and curiosity about this branch of human activity.

Nowadays, both the knowledge of science and the way in which it is approached have become more important than ever. Science is relevant to everyone's life and an understanding of science has turned into an essential tool for people in their efforts to achieve their goals. Hence the great importance assigned to how science is taught and learnt.

OECD reports through the publication of PISA results -based on an average across OECD countries- show that $18 \%$ of 15 year-olds do not attain the baseline proficiency Level 2 of 6 in science. At that level, students have an inadequate scientific knowledge to provide possible explanations in familiar contexts or to draw conclusions based on simple investigations. For instance, students whose proficiency in science is limited to Level 1 -on that 1-to-6 scale- will surely find it difficult to fully participate in society at a time when science and technology play such a large role in daily life (OECD, 2010).

An understanding of science and technology is central to a young person's preparation for life in modern society. It enables the individual to become fully integrated into a society where science and technology play a highly significant role. In this regard, it is worthy highlighting that while $95 \%$ of students reported that science was important to understand the natural world and $92 \%$ said that advances in science and technology usually improve people's living conditions, only $57 \%$ said that science is very relevant to them personally (OECD, 2007).

Scientific literacy is more than the simple reproduction of traditional school science knowledge, and requires a set of skills among which stand out identifying scientific issues, explaining phenomena scientifically, and using scientific evidence. It still seems necessary, perhaps more than ever before, to avoid a teaching of science based on presenting an isolated collection of facts to be memorised.

Because video games encourage players to compare the rules of whatever game they are playing to what they have learned elsewhere (Prensky, 2001), a suggestion is made to learn science through a video game. Schools need to find an educational application for many tools that may not have been originally 
designed with such a purpose in mind, but which are meaningful in students' everyday life.

In this respect, the educational potential of computer games has increasingly become a subject for discussion and research during the past few years. A number of overviews (e.g. de Freitas, 2006; Egenfeldt Nielsen, Smith \& Tosca, 2008; Mitchell \& Savill-Smith, 2004) describe the educational advantages and disadvantages of such games when they are used in science education, as well as in other educational areas.

This data supports the idea of including them in educational environments (among others, de Freitas, 2006; Facer \& Rudd, 2006; Kirriemuir, \& McFarlane, 2004; Sandford, Ulicsak,; Mitchell \& Savill-Smith, 2004; Steinkuehler, 2010; Panoutsopoulos \& Sampson, 2012) within the methodologies that advocate innovation in classrooms across different curricular areas.

The present paper has as its aim to explore how commercial video games provide innovative educational opportunities in the classroom that can bring children and adults into these new digital spaces. Our attention specifically focuses on the general concerns according to which games and simulations are not necessarily linked to scientific content and may not necessarily promote scientific understanding. This was the reason which made us decide to analyse the utilisation of the Spore video game as a learning resource in a Biology class of 4th grade students.

After considering the need to design educational settings in elementary and secondary education where students could engage with science, the discussion moves on to some of the latest research aimed at exploring educational possibilities connected to science contents through the use of commercial video games. The study finishes presenting our theoretical framework, which can help to understand what happens in the learning experience analysed. This aim was pursued using some of the learning principles built into good video games highlighted by James Paul Gee (2007). A number of tenets coming from the constructivists' conception of teaching and learning are considered as well.

\subsection{Video games in formal learning contexts}

Several studies indicate that playing computer games in a science classroom can support the development of students' conceptual understanding about scientific phenomena and theories. They can be used as a reflective and meta-cognitive tool, or an artefact, which helps to make teachers aware of the extent to which students can use and apply scientific concepts and theories in contextualised situations (Nilsson \& Jakobsson, 2010).

Along these lines, Barab and Dede (2007) argue that video games can offer contextualized learning situations in which students have the chance to broaden their understanding of science-related topics. In their study, students showed an increased knowledge of water quality concepts, balancing scientific and socio-economic factors, and they additionally learned how to conduct a scientific inquiry.

The work developed by Neulight and her colleagues' has shown us that computer games can offer the students embodied experiences in complex domains which are otherwise difficult or impossible to access in ordinary science classrooms. It is also argued that dynamic representations provide more authentic and explicit representations than students would otherwise be able to observe in the classroom (Neulight, Kafai, Kao, Foley \& Galas, 2007).

Similarly, Magnussen (2005) conducted a study where students had to solve a forensic case investigation, which would have been impossible to do in a traditional class. The game created a learning context in which students worked in groups creating tools that allowed them to investigate the case, and to discuss different problems as they gradually arose.

In addition to this, Squire and Jan (2007) suggest that educational efforts must be focused on helping students to think scientifically and to use scientific arguments, so that they can deal with the problems that they are likely to face in today's society.

The results of the research work carried out by Nilsson and Jacobsson (2010) reveal that the use of computer games such as SimCity 4 in meaningful science classroom contexts may contribute to create an educational context where the understanding of the embedded scientific content becomes easier.

The conclusions drawn from all these studies lead us to state that games and simulations which are not strictly linked to scientific content can promote scientific understanding within an appropriate learning context. In that sense, it is necessary to insist on something that Squire and Jenkins (2003) had already stressed, namely: the need to take into account the versatility of the game, the academic field, the pedagogical model, and the different strategies followed in order to explore the educational potential of any video game.

\subsection{The Spore video game as a problematic learning tool}

Spore (Electronic Arts, 2008) is a simulation and strategy game where the player develops a species through five evolutionary stages. The player starts with a microscopic organism and, as the game progresses, that organism develops into a complex creature with social and intellectual features. The game gives users the ability to "evolve life," or customize creatures by giving them traits that affect their ability to survive and prosper. Since its release date, in September 2008, there has been controversy over the educative potential of this video game. On the one hand, some scientists have pointed out the problems involved in seeing this game as a way to learn biology; on the other and, some scholars and educators see the game as a way to engage students in natural science.

According to Bohannon (2008b), the players' ability to customize their creatures using spore is equivalent to a glorified Mr. Potato Head game.

In allowing students to control how a creature evolves, Spore employs a process of "external manipulation" that mainstream scientists would reject as unscientific, says Barbara Forrest, a professor of philosophy at Southeastern Louisiana University, (Cavanagh, 2009).

Although there is considerable support in the field of game research in favour of using games in education, the treatment of scientific principles in Spore requires a careful examination (Bean, Sinatra \& Schrader, 2010). The depiction of evolutionary processes offered by this video game contains some scientific biases (Bohannon, 2008a, 2008b; Sinatra, Brem, \& Evans, 2008). As a result, players cannot observe genetic variability over time or even within that particular species. On the contrary, Spore offers the possibility of completely changing the design of 
a creature at once. The game fails to depict the variation and randomness of evolution, the natural process of selection and geological time.

The theory of evolution, advanced by Charles Darwin, states that any living form has evolved over millions of years through the process of natural selection along with random mutation.

On the other hand, there are some favourable responses from some scholars, who welcome Spore's interactive, engaging approach to the topic despite a few of its features compromising strict scientific accuracy for fun. For a number of academic experts familiar with debates regarding Spore or who have seen demonstrations of it, the game represents a clever way to raise students' interest in evolution (Cavanagh, 2009). "Even the things that it gets wrong, it could be a teachable moment," says Joe Meert, a geologist from the University of Florida (Cavanagh, 2009). There is also a conviction that the educational use of the game could spark interesting discussions about what might be happening in other planets and about the discovery of life in space revealing that it is not as evolved as it is in our world, or perhaps it is actually more evolved (Donahoo, 2008).

Each of the above perspectives provide different ideas about what it is to learn and, consequently, about the role "played" by the player within the game, the mental processes that it will require, and, ultimately, about the educational potential of the Spore video game.

In a similar vein, there are also different ideas about what a science lesson inside the classroom requires: rote learning, content reproduction tasks, and the figure of the teacher as the bearer of knowledge; as opposed to learning constructed through interactions between learners and the teacher as a guide and an instigator.

From our perspective, students are not seen as passive receivers of information but as individuals who actively carry out exploration processes.

Moreover, the main concerns about the use of Spore as an educational tool seem to come from considering the game as an isolated tool. In our research experience, the game was just a tool, as well as the debates, the academic book, the way in which the teacher interacted with the students, etc. The misconceptions over the simulation that Spore presents must be known before taking it into a classroom as a learning tool. This kind of practice is quite different from the perspective which exclusively contemplates the player, the game, and, in this case, the scientific biases contained in the depiction that it presents. Introducing a game as a learning tool always requires a prior examination of the game and a reflection on the pedagogical model to be followed by the teacher (Bean et al. 2010).

\subsubsection{Inside the Spore video game}

This video game allows players to design their own forms of life from unicellular organisms to interplanetary species. The game begins when a meteor crashes into a sea of an uninhabited planet. The body that will subsequently be controlled by the player (a unicellular organism) forms when this piece of rock disintegrates underwater.

The cell stage simulates microscopic life. Movements are limited to a two-dimensional plane, although it is assumed that the cell is immersed in water in a three-dimensional space. During this stage, the player selects the most important attributes of the cell, including size or whether it is carnivorous or herbivorous. The main objective is to eat and avoid predators. Food not only repairs the damage to health provoked by the environment or other species, but also earns DNA points, which can be used to improve and update parts of the body. Once you collect a specific number of DNA points, the organism "evolves" developing legs and leaving the water environment.

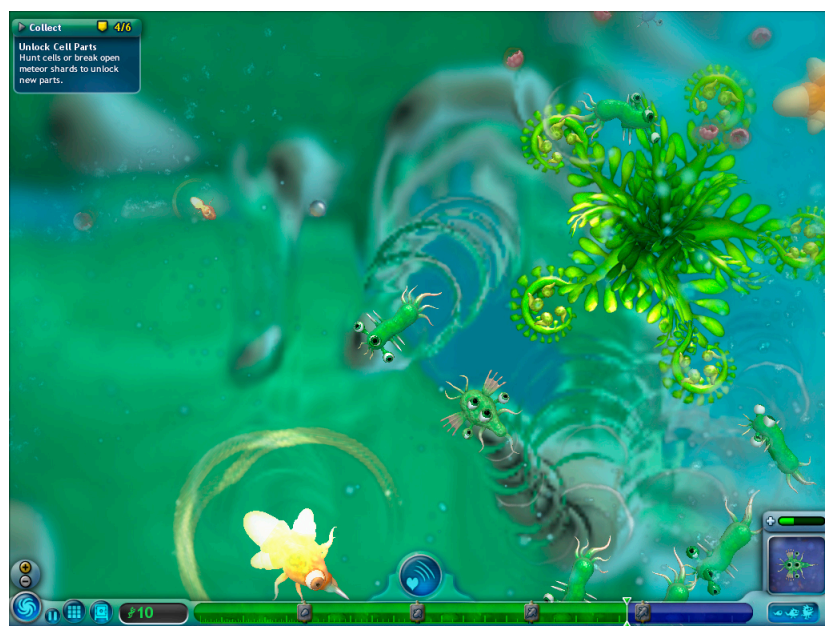

Figure 1. Screenshot of the first level

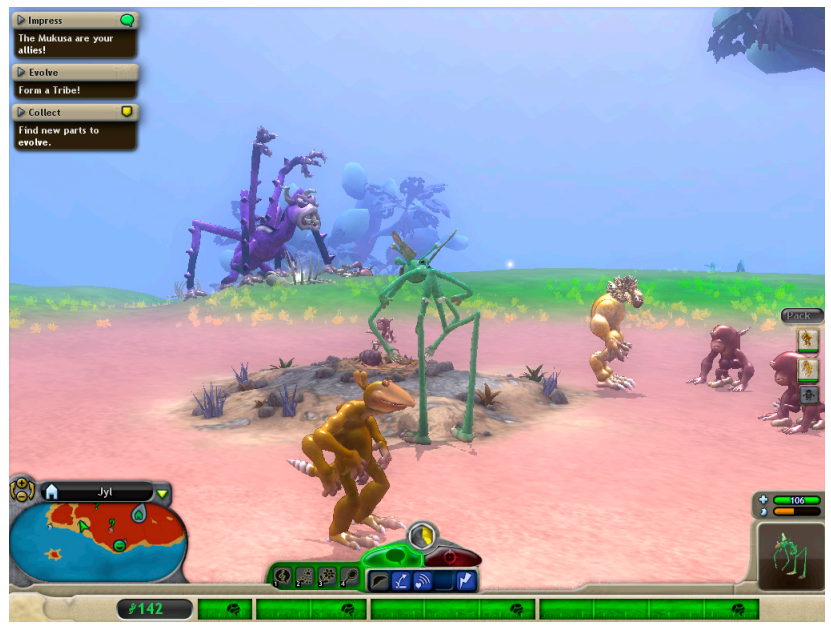

Figure 2. Screenshot of the second level

In the second stage, the protagonist of the video game becomes a land creature. On land, the main activities are eating and, again, collecting genetic material. However, here the player can direct the creature across the landscape looking for other species, against which, once they are found, the player will have two options. By attacking, the extinction of the other species arises as a new goal, or, in contrast, that other species can be befriended by the player. The modification of the different parts of the creature is known as "call mate," and can be carried out through a process that tries to simulate sexual reproduction. In this way, the player has the chance to access the 'Creature Creator' menu, where it is possible to manipulate the creature's characteristics (e.g. height, colour, type of mouth, eyes, etc.). Upon leaving this screen, the new creature is born immediately incorporating all the changes made by the player.

Once the creature has advanced a predefined number of times, it enters the tribal stage, where the species acquires sentience and culture. From this point onward, it no longer evolves on a biological level. The subsequent phase, where the player has to guide a civilization, brings some aspects related to sociology, such as the division of labour, public opinion or religious movements, and the possibility of creating buildings and 
managing resources. In the last phase, the player controls an intergalactic empire with the aim of conquering the known galaxy through spaceships.

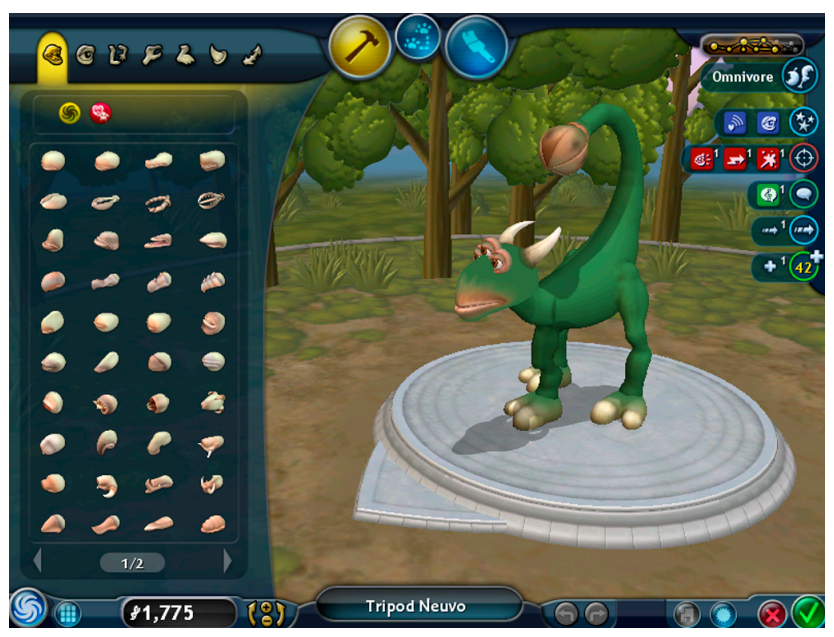

Figura 3. Screenshot of the 'Creature Creator' menu

Only the first two phases of the game have been used in our research experience, located within the biology subject and more specifically within the unit dedicated to the theory of evolution.

From the evolutionary biology perspective, some of the liberties that Spore takes with the science of evolution present an essentialist view, according to which organisms' qualities cannot change. It also encourages the problematic belief that evolution is goal-directed (Owens, 2012) i.e. the idea that organisms change their characteristics to better fit their environments, which is in direct conflict with the Darwinian views about evolution. Finally, it contains no notion whatsoever of randomness associated with natural selection and evolution, thus implying that some control is exerted by an intelligent agent.

\subsection{Learning principles built into Spore}

Before hastily drawing conclusions about the educational potential of this video game, both for and against, as educational psychologists interested in learning processes, it seems necessary for us to examine the role of Spore video game in a formal learning context, particularly, the $4^{\text {th }}$ grade biology class.

If the educational potential of a video game were assessed purely on the basis of the accuracy level in the simulation that it presents, hardly any game would pass the test. Moreover, it becomes necessary to reflect on whether hearing and reading about evolution during lessons, in order to make tests on the theoretical content, is the best way to learn about Darwinian evolution... or anything else.

Video games have taught us that a good game teaches the player primarily how to play that game and, then, to be able to generalize it to other contexts (Squire, 2011).

With a view to understand the learning processes that took place in our research context, it seemed useful for us to analyse that experience in the light of some learning principles, outlined by Gee, which are built into some video games. These principles mainly refer to two areas of current research:

- Situated cognition, according to which human learning is not just a matter of what goes on inside people's heads but something fully embedded in a material, social, and cultural world; and
- Connectionism, an area of work that stresses the ways in which human beings are powerful pattern recognisers. This body of work argues that humans think well when they reason on the basis of patterns that they have picked up through their experiences in the world -i.e. patterns which can become generalized.

Regarding the above, for us, literacy -in our specific case, literacy about Darwinian evolution and natural selectionrequires more than simply being able to "decode" and because it requires people to be able to participate in certain sorts of social practices, it becomes necessary to focus not only on codes or representations but also on the domains where such codes and representations are used (Rogoff, Matusov \& White, 1996).

Our introduction of the Spore video game as a learning tool for five 50-minute-long sessions in which the students were organized in 5 groups, each one of them with a computer and a copy of this video game, actually meant creating a new context at least new with respect to regular lessons- where students could learn and think about evolution and natural selection. They used their previous knowledge and abstract ideas, the simulation of evolution presented in the Spore video game, and the academic knowledge from the previous sessions.

In that context, the educational potential of this video game mainly has to do with how the teacher and the students use it. How do students play? What questions do they have in mind while playing? What relationships do they establish between the simulations presented in the Spore video game and the academic knowledge about evolution? What role do their previous ideas play when they are inside the game?

In our opinion, answering these questions provides a more accurate way of understanding the learning promoted by using the Spore video game in a $4^{\text {th }}$ grade Biology class than if our attention only focused on the scientific misconceptions built into the video game, which actually proved useful in some sessions to examine Spore for non-normative scientific concepts, and to compare it with the academic knowledge.

Although the learning principles outlined by Gee (2007) are considered to be "built into" video games, only some of them have been selected here. This selection was made after a first approach to the data gathered, and regarding the social nature of the learning processes which took place in our research experience, as well as the role played by the video game between students, between students and their teacher, and between all of them in relation to the content area inside the classroom (Checa, García-Varela, Monjelat, Herrero, del Castillo, 2013).

After listing and defining the principles selected, it is necessary to discuss them briefly.

Probing Principle: Learning is a cycle of probing the world (doing something); reflecting in and on this action and, on this basis, forming a hypothesis; reproving the world to test this hypothesis; and then accepting or rethinking the hypothesis.

Multiple Routes Principle: Multiple ways exist to make progress or move ahead. This allows learners to make choices, rely on their own strengths as well as on their learning and problem-solving styles, while also exploring alternative styles.

Situated Meaning Principle: The meanings of signs (such as words, actions, objects, artefacts, symbols, texts...) lie in the experience embodied. These meanings are not general or decontextualized. 
Teaching evolution and natural selection is different from any other topic in science because of the possibilities for misconceptions and misinterpretations. There are many factors which may impede students' understanding, such as personal, social, or religious beliefs that may not match, or that may be at odds with the ideas associated with Darwinian evolution (Schrader, 2012). In our research experience, the Spore video game has revealed itself as a scenario where students can manage and probe their previous ideas in relation to the academic knowledge. In this regard, the game has worked as an incentive for students to form hypotheses, to probe, and later to rethink their hypotheses.

Despite the organization and timing in each one of the five sessions, which were the same for all the students, they had the opportunity to play, to form hypotheses and to think about evolution and natural selection, via two different thought processes. That choice was built into the game and related to the way in which their organism evolved, either competitively or cooperatively. This distinction in game play, which has to do with the different ways in which species relate to each other in the natural world, encouraged the discussion between students and their teacher.

One might wonder what would happen if some students had played previously with this video game outside school. Actually, it did not happen in our research experience, but anyway, considering the situated meaning principle, the need arises to think about the role played by the Spore video game as a virtual world where it is possible to probe and generate hypotheses about evolution and natural selection, but also as a learning tool integrated into a classroom, within a subject, and mediated by the curricular content and the way in which the teacher presents it. By considering Spore not as a stand-alone tool inside the classroom, the misconceptions about evolution that it might promote can become topics for discussion among students. This requires a teacher who is well-trained both in evolutionary biology and in the mechanics presented by the video game.

\section{METHODS}

\subsection{Research context}

The project presented in this paper was developed from a qualitative analytical perspective based on narrative and ethnographic approaches (Anderson-Levitt, 2006; Connelly \& Clandinin, 2006; Hollingsworth \& Dybdahl, 2007; Pink, 2006) and includes a micro-ethnographic analysis of multimodal discourses (Gee \& Green, 1998).

Our research took place in a public Secondary School located in Coslada (Madrid) during a whole school year. This paper offers the results of a workshop carried out during a month with a group of $224^{\text {th }}$ grade students, aged 15-17, and their Biology teacher.

The workshop was organized in two stages. The first one was dedicated to the design of classroom activities together with the teacher, trying to integrate the sessions in which the video game was going to form part of ordinary classes by relating the activities contained in the video game to the curricular content on which students have worked the day before. The second part consisted in the development of five 50-minute-long sessions for which the students were organized in 5 groups, each one of them with a computer and a copy of the Spore video game. The first 30 minutes of each class were dedicated to play Spore. The remaining 20 minutes were spent in discussions between the five groups about the main issues emerged from the game, it all under the teacher's guidance.

\begin{tabular}{|c|c|}
\hline \multicolumn{2}{|c|}{ Workshop: 5 sessions } \\
\hline \multicolumn{2}{|c|}{ Workshop structure } \\
\hline Play to video game & $\begin{array}{l}\text { Think from the } \\
\text { experience with the } \\
\text { video game }\end{array}$ \\
\hline $\begin{array}{l}\text { Small group } \\
\text { discussion }\end{array}$ & Group discussion \\
\hline
\end{tabular}

Figure 4. Workshop phases and main activities developed

\subsection{Data analysis}

The process of collecting and gathering the data that had to be the heart of our research, as usual in ethnography, was mediated by a number of instruments. Once inside the classroom, an attempt was made to record everything that is observed considering the relevance of unexpected phenomena (del Castillo, Herrero, García-Varela, Checa, Monjelat, 2012). In this sense, many tools helped us to record and analyse data density, including audio and video recordings, pictures, the materials handled and generated by participants in each session, sessions' summaries, etc.

After completing the workshop, all the video recordings were segmented and analysed using qualitative data analysis software, like NVivo and Atlas.ti. This allowed successive moments in the classroom to be defined; these were subsequently transcribed in order to explore the activities of children and adults as related to specific practices, and supporting several pedagogical strategies.

A micro-ethnographic analysis of multimodal discourse (Gee \& Green, 1998) served to analyse the learning processes and outcomes related to evolution and natural selection, as well as the awakening of interest among students. More specifically, our attention focused on looking for evidence of students developing skills such as identifying scientific issues, explaining phenomena scientifically or using scientific evidence. From this perspective, some examples can be shown of how the aforementioned learning principles (Gee, 2007) were enacted during the workshop.

\section{FINDINGS AND DISCUSSION}

The data revealed that, during our five sessions, the students performed a number of strategies to play the Spore video game while exploring real and virtual environments together with their teacher. Furthermore, they discussed different theories of evolution that might be present in the video game and wondered whether those theories reflected faithfully or not the Darwinian theory of evolution and natural selection. In such a way, also the previous knowledge and abstract ideas of students were present.

The game consequently provides an opportunity to develop the content of the biology subject, exploring the virtual universe from the perspective of science. The teacher took advantage of this feature to reach the following classroom objectives:

- To jointly reflect on evolutionary theories bearing in mind the game experience

- To establish relationships between the simulations presented in the video game and the theories of evolution 
In order to achieve the preceding aims, the teacher had previously explained the theories of evolution in the regular lessons. The students were able to play Spore equipped with their biology books and written notes. The students' group willingness to play made it possible to develop spontaneous discussions about possible relationships between the theories advocated by the game and those prevailing in the scientific world.

In this context, the role of the teacher acquired a double dimension. Firstly, the teacher worked as a guide to promote discussion within each group during the first part of the classes and with the whole group of students during the second part. In that sense, the teacher resolved doubts or misunderstandings linked to Darwinian evolution and other theories. And secondly, the teacher presented and conducted the workshop's structure, explaining the tasks and their main purposes.

Below can be found some excerpts which reflect the aforementioned issues, revealing what was the dynamics followed inside the classroom from the introduction of the game. The following excerpt shows how the teacher guides the conversation to help students to think about the curriculum from the students' experience with the game:

Excerpt A. Reflecting on the playing experience with the video game

IES Manuel de Falla 4th grade Biology Class. Session No.3

Discussion between a group of students (S1, S2) and their teacher (T)

[...]

1. S1: It follows a Darwinian strategy.

2. T: Why do you say that?

3. S1: Because natural selection happens.

4. T: But why?

5. S1: Because we can improve our creature, some parts of its anatomy.

6. S2: That is Lamarckian.

7. T: Well, it seems to have some elements of each theory. What elements does it have from Darwinian evolution?

8. S1: If you do not eat, another larger animal could eat you.

9. T: And what about Lamarck?

10. S2: When you have to select the animal's anatomy in the game that can cause that the creature evolves. Then, although the creature is evolving, this evolution is not caused by the environment.

This short passage of interaction between the students and their teacher shows how the former can link what they have experienced in the game with the concepts and ideas examined in the class sessions dedicated to Darwinian evolution and other theories. What is more, the video game acts as a virtual scenario where students can experiment and compare their previous ideas, the academic knowledge and the rules of the simulation presented in the game. In this way, they can clarify or even go deeper in terms of understanding about biological evolution and natural selection, which has to do with the idea of the Multiple Routes Principle and the Probing Principle (Gee, 2007). Students had the chance to probe different paths to obtain different results, so, from this experience, they can learn by generating and testing their hypotheses over the virtual world. Then, students are continuously making choices and exploring alternatives that help them in the process of forming, accepting or rethinking the hypothesis that they use to explain both the virtual and the real world.

Moreover, this excerpt also shows how students sometimes used scientific concepts (10) on the basis of a relevant scientific language, whereas they used everyday language on other occasions (8). This common ground for two different ways of talking represents an ideal basis for students to be able to broaden their understanding about a science-related topic. The integration of a technology which is undoubtedly meaningful for students, as video games are, into formal learning, can facilitate the emergence of these spaces.

Another point which deserves to be highlighted is how the game works in this case as a tool that helps students to use their previous ideas for the achievement of new learning outcomes.

\section{Excerpt B. Reflecting on the workshop experience}

IES Manuel de Falla 4th grade Biology Class. Session No.6

Conversation between a researcher (R1), a student (S1) and the teacher (T1)

1. R1: What do you think about this video game?

2. S1: The game is cool, right? I do not think that people, while they are playing, think in evolutionary terms. I mean, if you play in a classroom then you may think about it, but when you are at home you think more like... "Oh, I will kill this stupid bug", which, actually, I think it is related with Lamarck's theory.

3. T1: Sure, that is why we do it here.

The content of this excerpt refers us back to the situated meaning principle, since the student stresses the importance of context as well as the presence and work of adults as key elements for the learning experience that took place in the classroom. Furthermore, as the teacher said during the interviews, the video game became a tool contributing to sensitise herself about the extent to which students are able to use and apply scientific concepts and theories in contextualised situations.

This is an example of how the Situated Meaning Principle can be found in the utilisation made of the Spore video game within this workshop. The meanings of evolution and natural selection and the video game dynamics merged during the playing experience, so students became aware of how they apply their knowledge through different paths when faced with different contexts. As the teacher explained in the interviews, the classroom represents a fantastic setting for playing and deeply reflecting on some questions that they will use more unconsciously in other scenarios.

Students discussed which physical traits were better for their creatures. Having scientific debates on cause and effect proved to be valuable, especially when these arguments stemmed from a learning experience where students had been able to draw comparisons between their previous knowledge, the academic knowledge, and the gaming experience.

\section{FINAL THOUGHTS}

Our paper has tried to show how students' understanding of evolution and natural selection processes can be broadened if Spore is not regarded as an isolated learning tool -which is even more than just introducing it in a Biology classroom and then wait to see what happens.

Spore, just like any other video game, cannot change the way in which biology is taught in schools. Instead of adopting that naive point of view, our intention was to use this video game just as an interactive way for students to probe their previous ideas and their academic knowledge about evolution and natural selection.

Here it is important to draw a clear-cut distinction between a teaching methodology and a learning tool -the utilisation of a video game in the classroom fits better with the second one. 
Teaching evolution and natural selection is different from that of any other topic in science because of the possibilities for misconceptions and misinterpretations. Numerous factors may impede students' understanding, such as personal, social, or religious beliefs that may not match, or even be at odds with the ideas linked to Darwinian evolution (Schrader, 2012).

In our research experience the video games took place in dynamics between students encouraged by the teacher. Thus, Spore served as instigator of debate, since it allowed students to identify their intuitive knowledge and previous ideas about evolution and natural selection, in order to compare it with the academic and objectified knowledge. The simulation presented in the game -although far from being accurate about the simulated reality-becomes a scenario within the classroom where students can generate and test hypotheses; see representations of theoretical concepts previously examined in regular lessons; and lead discussions on specific issues or misunderstandings about biological evolution.

The teacher detected some of these issues and misunderstandings (thanks to the game) just when the students could clarify and implement their knowledge on this subject.

The expectations were that game designers could come closer to actual simulated evolution but also that teachers could learn to create learning contexts where students could develop their own interest in the subject -not just to give the right answer, or to pass the final exam.

The main contribution made by Spore to the teaching and learning process lies, on the one hand, in how it helps students to identify and relate their abstract conceptions about biological evolution to the theoretical concepts previously studied in the classroom; and, on the other hand, in the knowledge that teachers can obtain about their students' understanding of all these concepts.

Probably, the central doubt about Spore is whether it can be both scientifically accurate and fun (Robertson, 2008). In relation to this issue, it seems obvious to us that those who did not support the educational utilisation of this game were expecting a game strictly linked to curricular contents.

The virtues and drawbacks of any video game must necessarily be known by teachers who decide to introduce them in the classroom as learning tools. These virtues and the drawbacks could work as elements to be used by students in their learning processes, in order to compare with the academic knowledge, in order to use and prove their previous ideas, etc. unless teachers were expecting a game that could play the same role as a textbook.

Finally, it is our conviction that the educational potential of Spore, like that of any other video game, lies in the teachers' ability to create immersive contexts that can be later integrated into the curricula -rather than in the work of software developers.

\section{REFERENCES}

Anderson-Levitt, K. M. (2006). Ethnography. In J. L. Green, G. Camilli \& P. B. Elmore (Eds.), Handbook of complementary methods in education research (pp. 279-296). Washington DC: AERA \& LEA.

Barab S., \& Dede, C. (2007). Games and immersive participatory simulations for science education: an emerging type of curricula. Journal of Science, Education and Technology, 16 (1), 1-3. doi: 10.1007/s10956-007-9043-9

Bean, T. E., Sinatra, G. M., \& Schrader, P. G. (2010). Spore: Spawning evolutionary misconceptions? Journal of Science Education and Technology, 19 (5), 409-414. doi: 10.1007/s10956-010-9211-1
Bohannon, J. (2008a). 'Spore' Documentary Spawns Protest By Scientists Who Starred in It. Science, 322 (5901), 517. doi: 10.1126/science.322.5901.517a

Bohannon, J. (2008b). Flunking spore. Science, 322 (5901), 531. doi: $10.1126 /$ science. $322.5901 .531 \mathrm{~b}$

Cavanagh, S. (2009). Game enables users to guide evolution on screen. Education week, 12. Retrieved from http://www.edweek.org/ew/articles/2008/09/12/04spore.h28.html

Checa, M., García-Varela, A. B., Monjelat, N., Herrero, D., \& del Castillo, H. (2013). Participatory Culture and skill for new media learning. In B. Bigl \& S. Stoppe (Eds.), Playing with Virtuality, Theories and Methods of Computer Game Studies. Frankfurt am Main: Peter Lang.

Connelly, F. M., \& Clandinin, D. J. (2006). Narrative inquiry. In J. L. Green, G. Camilli \& P. B. Elmore (Eds.), Handbook of complementary methods in education research (pp. 477- 489). Washington DC: AERA \& LEA.

De Freitas, S. (2006). Learning in immersive worlds: A review of gamebased learning. Bristol, London: JISC.

Del Castillo, H., Herrero, D., García-Varela, A. B., Checa, M., \& Monjelat, N. (2012). Desarrollo de competencias a través de los videojuegos deportivos: alfabetización e identidad. RED. Revista de Educación a Distancia, 11 (33)

Dewey J. (1910). How We Think. New York: Dover. doi: 10.1037/10903-000

Donahoo, D. (2009, November 5). Five reasons to use Spore in classroom [Web log message]. Retrieved from http://www.wired.com/geekdad/2009/11/5-reasons-to-use-spore-inthe-classroom/

Egenfeldt Nielsen, S., Smith, J. H., \& Tosca, S. P. (2008). Understanding Video Games: The essential Introduction. New York: Routledge.

Electronic Arts (2008). What is SPORE? Retrieved from http://www.spore.com/what

Gee, J. P., \& Green, J. L. (1998). Discourse analysis, learning and social practice: A methodological study. Review of Research in Education, $23,119-171$.

Gee, J. P. (2007). What video games have to teach us about learning and literacy. New York: Palgrave McMillan.

Hollinngsworth, S., \& Dybdahl, M. (2007). Talking to learn. The critical role of conversation in narrative inquiry. In D. J. Clandinin (Ed.), Handbook of narrative inquiry. Mapping a methodology (pp. 146176). Thousand Oaks, CA: Sage. doi: 10.4135/9781452226552.n6

Kirriemuir, J. \& McFarlane, A. (2004). Literature Review in Games and Learning. Bristol: Graduate School of Education, University of Bristol.

Magnussen, R. (2005). Learning games as a platform for simulated science practice. Conference proceedings of DiGRA 2005 conference: changing views - worlds in play. Vancouver, Canada.

Mitchell, A. \& Savill-Smith, C. (2004). The use of computer and video games for learning. A Review of the Literature. London: Learning and Skills Development Agency.

Neulight, N., Kafai, Y. B., Kao, L., Foley, B., \& Galas, C. (2007). Children's participation in a virtual epidemic in the science classroom: making connection to natural infectious disease. Journal of Science Education and Technology, 16(1): 47-58. doi: $10.1007 / \mathrm{s} 10956-006-9029-\mathrm{z}$

Nilsson, E. M., \& Jakobsson, A. (2010). Simulated Sustainable Societies: Students' Reflections on Creating Future Cities in Computer Games. Journal of Science Education and Technology, 20(1), 33-50. doi: 10.1007/s10956-010-9232-9.

OECD (2007). PISA 2006: Science Competencies for Tomorrow's World. Executive Summary. Retrieved from OECD website: http://www.oecd.org/pisa/pisaproducts/pisa2006/39725224.pdf

OECD (2010). PISA 2009 at a Glance. Retrieved from OECD website: http://www.oecd.org/pisa/46660259.pdf

Owens, T. (2012). Teaching intelligent design or sparking interest in science? What players do with Will Wright's Spore. Cultural Studies of Science Education, 7(4), 857-868. doi: 10.1007/s11422-012-9383-

Panoutsopoulos, H., \& Sampson, D. G. (2012). A study on exploiting commercial digital games into school context. Journal of Educational Technology \& Society, 15(1), 15-27.

Pink, S. (2006). Doing visual ethnography: Images, Media and Representation in Research. London: SAGE.

Prensky, M. (2001). Digital Game-Based Learning. London: McGrawHill. 
Robertson, M. (2008, September). The creation simulation. Seedmagazine.com. Retrieved from http://seedmagazine.com/content/print/the_creation_simulation/

Rogoff, B, Matusov, E., \& White, C. (1996). Models of teaching and learning: Participation in a community of learners. In D. Olson \& N. Torrance (Eds.), Handbook of education and human developments: New models of learning, teaching and schooling. London, UK: Basil Blackwell.

Sandford, R.; Ulicsak, M.; Facer, K., \& Rudd, T. Teaching with Games (2006). Using commercial off-the-shelf computer games in formal education. Bristol: Futurelab.

Schrader, P., Deniz, H., \& Keilty, J. (2012). Breaking SPORE: Aligning Video Game Affordances to Science Pedagogy. In P. Resta (Ed.), Proceedings of Society for Information Technology \& Teacher Education International Conference 2012 (pp. 2618-2625). Chesapeake, VA: AACE.

Sinatra, G.; Brem, S., \& Evans, E. (2008). Changing minds? Implications of conceptual change for teaching and learning about biological evolution. EvolEduc Outreach, 1, 189-195. doi: 10.1007/s12052-008-0037-8

Stake, R. (2006). Multiple Case Study Analysis. New York: Guildford.

Steinkuehler, C. (2010). Video games and digital literacies. Journal of Adolescent \& Adult Literacy, 54(1), 61-63. doi: 10.1598/JAAL.54.1.7

Squire, K. (2011). Video games and learning: Teaching and participatory culture in the digital age. Cambridge, MA: Teachers College Press.

Squire, K., \& Jan, M. (2007) Mad city mystery: developing scientific argumentation skills with a place-based augmented reality game on handheld computer. Journal of Science Education and Technology, 16(1): 5-29. doi: 10.1007/s10956-006-9037-z

Squire, K., \& Jenkins. H. (2003). Harnessing the power of games in education. Insight, 3(1): 5-33.

\section{ACKNOWLEDGMENT}

The present paper was carried out within the framework of the research project "Video games and situated learning; awareness of identity formation processes in children and teenagers" funded by the UAH. Reference: UAH2011/HUM-003 